\title{
A single tree model to consistently simulate cooling, shading, and pollution uptake of urban trees
}

\author{
Rocco Pace ${ }^{1,2}$ (D) $\cdot$ Francesco De Fino ${ }^{3} \cdot$ Mohammad A. Rahman $^{4} \cdot$ Stephan Pauleit $^{4} \cdot$ David J. Nowak $^{5} \cdot$ Rüdiger Grote $^{1}$
}

Received: 3 April 2020 / Revised: 24 September 2020 / Accepted: 6 October 2020 / Published online: 18 October 2020

(C) The Author(s) 2020

\begin{abstract}
Extremely high temperatures, which negatively affect the human health and plant performances, are becoming more frequent in cities. Urban green infrastructure, particularly trees, can mitigate this issue through cooling due to transpiration, and shading. Temperature regulation by trees depends on feedbacks among the climate, water supply, and plant physiology. However, in contrast to forest or general ecosystem models, most current urban tree models still lack basic processes, such as the consideration of soil water limitation, or have not been evaluated sufficiently. In this study, we present a new model that couples the soil water balance with energy calculations to assess the physiological responses and microclimate effects of a common urban street-tree species (Tilia cordata Mill.) on temperature regulation. We contrast two urban sites in Munich, Germany, with different degree of surface sealing at which microclimate and transpiration had been measured. Simulations indicate that differences in wind speed and soil water supply can be made responsible for the differences in transpiration. Nevertheless, the calculation of the overall energy balance showed that the shading effect, which depends on the leaf area index and canopy cover, contributes the most to the temperature reduction at midday. Finally, we demonstrate that the consideration of soil water availability for stomatal conductance has realistic impacts on the calculation of gaseous pollutant uptake (e.g., ozone). In conclusion, the presented model has demonstrated its ability to quantify two major ecosystem services (temperature mitigation and air pollution removal) consistently in dependence on meteorological and site conditions.
\end{abstract}

Keywords Microclimate model $\cdot$ Transpiration $\cdot$ Shading $\cdot$ Stomatal conductance $\cdot$ Soil water availability $\cdot$ Urban green spaces

\section{Introduction}

The increasing occurrence of heatwaves due to global warming (Perkins et al. 2012; Baldwin et al. 2019) presents

Rocco Pace

rocco.pace@iret.cnr.it

1 Institute of Meteorology and Climate Research-Atmospheric Environmental Research (IMK-IFU), Karlsruhe Institute of Technology (KIT), Garmisch-Partenkirchen, Germany

2 Institute of Research on Terrestrial Ecosystems (IRET), National Research Council (CNR), Porano, Italy

3 Department of Informatics, Bioengineering, Robotics and Systems Engineering (DIBRIS), University of Genoa, Genoa, Italy

4 Chair for Strategic Landscape Planning and Management, School of Life Sciences Weihenstephan, Technische Universität München, Munich, Germany

5 USDA Forest Service, Northern Research Station, Syracuse, NY, USA a serious threat to human health (Watts et al. 2019). For example, the 2003 heatwave in Europe caused more than 70,000 deaths (Robine et al. 2008) and the heatwave-related premature mortality is expected to increase at the global scale (Guo et al. 2018). Extreme high temperatures are prevalent in cities, where the high percentage of sealed surfaces contributes to the so-called heat island effect (Oke 2002; Wilby 2003). Therefore, measures to mitigate the temperature stress are intensively discussed. The implementation of green infrastructure is arguably the most prominent suggestion to initiate this (Norton et al. 2015) and indeed, the associated cooling effect has been evaluated in many observational studies (Bowler et al. 2010; Rahman et al. 2020a). In particular, it is suggested to increase the number of urban trees in order to enhance the cooling effect (Zölch et al. 2016).

Trees reduce the air temperature in two ways: by preventing solar radiation from heating up surfaces below the canopy (shading) and by converting energy to latent heat flux through the transpiration of water released through the stomata of leaves (in the following termed cooling; Rahman 
et al. 2020a). However, these effects strongly depend on the tree dimensions and physiology and thus the climatic conditions (Rahman et al. 2018). In particular, low relative humidity (or high vapor pressure deficit) triggered by high temperature reflects a high transpiration demand. However, the actual transpiration is limited by the soil water availability. Insufficient water supply causes stomata closure and decreases the water uptake and thus the cooling effect of transpiration (Rötzer et al. 2019). Other meteorological factors that are positively related to evaporation are solar radiation, because stomata tend to open if the radiation is high, and the wind speed, which reduces the boundary layer thickness and thus the resistance to water transport from the canopy (Kramer 1983).

Several approaches have been considered to simulate the effect of vegetation on the micrometeorology in urban environments. The most prominent ones are computational fluid dynamics models that are built on fundamental fluid mechanics and thermodynamics laws and are used to calculate the interactions between trees and their surroundings (Buccolieri et al. 2018). Urban canopy models based on which the energy budget is determined with a simplified consideration of the flows represent a simpler approach (e.g., Lee and Park 2008; Krayenhoff et al. 2014; Zeng and Gao 2017). Recently, the use of large-eddy simulation models has been suggested for the estimation of the mitigating effect of vegetation on urban heat, although they currently do not fully consider the impact of evaporation (Li and Wang 2018). However, all these model types are computational demanding, difficult to parameterize, and very sensitive to the initial boundary conditions. Therefore, it is difficult to consider different species or individual properties, which diminishes their value as decision support tools for urban planning.

Urban forest-specific models represent a different group of models, most prominent in urban ecosystem research (Lin et al. 2019). These models focus less on the interactions between vegetation and the environment but more on the physical and physiological properties and processes of plants, that is, trees. A prominent example is the i-Tree model that can be used to estimate a broad range of ecosystem functions such as the air pollution removal, carbon sequestration, and building energy conservation (Nowak et al. 2008; Endreny et al. 2017). Among these services, energy estimates are related to the cooling function of trees (Scholz et al. 2018), but are mainly related to tree shade (Mcpherson and Simpson 1999). Because cooling is arguably the most important ecosystem service regarding the mitigation of future climate change effects in cities, this function must be calculated explicitly, that is, the effects of stomatal conductance and water limitation must be clarified. The combination of shading and leaf area or crown coverage or cooling and evapotranspiration has only been attempted in a few studies (Yang et al. 2013; Rötzer et al. 2019).
If evapotranspiration is calculated based on the stomatal conductance, another ecosystem service, that is, the gaseous pollutant uptake, can be physically considered. In contrast to particle deposition, gaseous pollutants, such as ozone, are primarily taken up through the stomata (Hosker and Lindberg 1982). When stomata are open, $\mathrm{O}_{3}$ diffuses into the intercellular space from the atmosphere and is almost immediately destroyed by antioxidant reactions with membrane lipids, moisture, and cell organelles in the apoplast (Tiwari et al. 2016). Stomatal $\mathrm{O}_{3}$ uptake depends strongly on stomatal conductance and therefore, uptake rates differ depending on the assimilation conditions or water supply of the plants (Fitzky et al. 2019). Among the various models that calculate stomatal uptake, few consider the soil water limitation, for example, the ozone deposition DO3SE model (Emberson et al. 2000; Büker et al. 2012). This type of model is primarily used to evaluate the effect on plants rather than on the environment because it was designed for the evaluation of trade-off between drought stress and ozone stress (Sicard et al. 2016). However, until very recently, we were not aware of any model that jointly considers the effects of limited water supply on both the cooling function and air pollutant removal of trees.

In this study, we introduce a single tree model coupled to a one-dimensional soil water model to consider the effect of drought stress on stomatal conductance and thus on cooling as well as air pollution removal functions. The objective is to demonstrate that the model works realistically and could be applied as a decision-support tool based on general available data. Therefore, we calculated the temperature mitigation (cooling and shading) of a common street-tree species (Tilia cordata) and evaluated these data with measurements from the literature. In addition, we use the evaluated model to demonstrate the potential impact of soil water conditions on the uptake of ozone.

\section{Methods}

\section{Study area and local data}

The study areas are located in Munich (Germany) and have different topographical features: Bordeaux Platz is an open green square and Pariser Platz is a circular paved square. Five trees of $T$. cordata with different morphological characteristics have been measured in each location (Table 1). Canopy cover was calculated from crown radii which were measured in eight inter cardinal directions and LAI was derived from hemispherical photographs captured during the fully leafed phase (June-August) as described in Rahman et al. (2017a). Trees at Bordeaux Platz were typically smaller than those at Pariser Platz.

Sap flux density measurements carried out from July 29 to August 31, 2015, were used to estimate the tree transpiration. 
Table 1 Average morphological characteristics of trees at the two study sites ( $D B H$ diameter at $1.3 \mathrm{~m}$ height, $L A I$ leaf area index)

\begin{tabular}{lllll}
\hline Sites & DBH $(\mathrm{cm})$ & Height $(\mathrm{m})$ & Canopy cover $\left(\mathrm{m}^{2}\right)$ & LAI \\
\hline Bordeaux Platz & $29.18 \pm 0.52$ & $15.12 \pm 0.21$ & $67.12 \pm 3.37$ & $2.41 \pm 0.19$ \\
Pariser Platz & $44.68 \pm 1.27$ & $16.78 \pm 0.29$ & $81.7 \pm 3.97$ & $2.54 \pm 0.18$ \\
\hline
\end{tabular}

Summer 2015 was an exceptionally hot and dry summer and represents a crucial time of year for evaluating the effect on stomatal conductance. Tree core samples were used to estimate tree age and determine sapwood area of trees which is the basis for determining sap flow rate. In order to facilitate the direct comparison of the trees, the water use was then scaled for each tree to a DBH and sapwood area at an age of 40 years.

The soil moisture potential was measured throughout the soil profile to a depth of $30 \mathrm{~cm}$ and local data, including the air temperature, pressure, relative humidity, and wind speed, were measured at the two study sites. Furthermore, the global radiation was measured at Bordeaux Platz; all data were continuously recorded at resolution of $15 \mathrm{~min}$. Precipitation data were derived from the Theresienstrasse weather station in Munich. Missing values on August 5th are due to vandalism-related measurement problems. For more details on the methodology, please see Rahman et al. (2017a).

\section{Model calculations}

\section{Transpiration, stomatal conductance, and $\mathrm{O}_{3}$ deposition velocity}

The transpiration flux $\left(T_{\mathrm{f}}, \mathrm{g} \mathrm{m}^{-2} \mathrm{~h}^{-1}\right)$ was calculated using the i-Tree Eco model methodology (Hirabayashi et al. 2015). The amount of water evaporating through stomata is controlled by the leaf and boundary layer resistances (Kramer 1983):

$T_{\mathrm{f}}=\frac{C_{\text {leaf }}-C_{\text {air }}}{\frac{1}{\mathrm{gs}}+R_{\mathrm{a}}} \cdot \frac{3600}{\mathrm{LAI}}$,

where $C_{\text {leaf }}$ is the water vapor concentration of evaporating surfaces within the leaf $\left(\mathrm{g} \mathrm{m}^{-3}\right), C_{\text {air }}$ is the water vapor concentration in the air $\left(\mathrm{g} \mathrm{m}^{-3}\right), 1 / \mathrm{gs}$ is the stomatal resistance ( $\mathrm{s} \mathrm{m}^{-1}, \mathrm{gs}=$ stomatal conductance), $R_{\mathrm{a}}$ is the aerodynamic resistance $\left(\mathrm{s} \mathrm{m}^{-1}\right)$, and LAI is the leaf area index.

The parameters $C_{\text {leaf }}$ and $C_{\text {air }}$ can be calculated as follows (Monteith and Unsworth 2013):

$C_{\text {leaf }}=\frac{M_{\mathrm{w}} e_{\mathrm{s}}}{R T}$

$C_{\text {air }}=\frac{M_{\mathrm{w}} e}{R T}$,

where $M_{\mathrm{W}}$ is the molecular weight of water $\left(18 \mathrm{~g} \mathrm{~mol}^{-1}\right), R$ is the universal gas constant $\left(8.314 \mathrm{~J} \mathrm{~mol}^{-1} \mathrm{~K}^{-1}\right), e_{\mathrm{s}}$ is the saturation vapor pressure $(\mathrm{kPa}), e$ is the vapor pressure ( $\mathrm{kPa}$ ), and $T$ is the temperature $(\mathrm{K})$.

The stomatal conductance of each layer of the canopy can be calculated based on the methods explained in Farquhar et al. (1980), Baldocchi (1994), and Harley et al. (1992):

$\mathrm{gs}=\frac{m A \mathrm{rh}}{C_{\mathrm{s}}}+\mathrm{gm}$,

where $m$ is the Ball-Berry coefficient, $A$ is the photosynthetic carbon flux into the leaf, rh is the relative humidity, $C_{\mathrm{s}}$ is the $\mathrm{CO}_{2}$ concentration at the leaf surface, and $\mathrm{gm}$ is the minimum stomatal conductance $\left(0.02 \mathrm{~mol} \mathrm{~m}^{-2} \mathrm{~s}^{-1}\right)$ when the stomata are closed $(A=0)$ assuming a cuticular resistance of 0 . The terms $m$ and gm are the slope and intercept of the relationship between assimilation and stomatal conductance, obtained by linear regression of gas exchange measurements.

The aerodynamic resistance $\left(R_{\mathrm{a}}\right)$ is calculated as follows:

$R_{\mathrm{a}}=\frac{u(z)}{u_{*}^{2}}$

where $u(z)$ is the mean wind speed at the height of the weather station $z\left(\mathrm{~m} \mathrm{~s}^{-1}\right)$ and $u_{*}$ is the friction velocity $\left(\mathrm{m} \mathrm{s}^{-1}\right)$.

The $\mathrm{O}_{3}$ deposition velocity ( $\mathrm{vd}$ ) can be calculated as the inverse of the sum of the aerodynamic $\left(R_{\mathrm{a}}\right)$, quasi-laminar boundary layer $\left(R_{\mathrm{b}}\right)$, and canopy $\left(R_{\mathrm{c}}\right)$ resistances, expressed in $\mathrm{s} \mathrm{m}^{-1}$ (Baldocchi et al. 1987):

$\mathrm{vd}=\frac{1}{R_{\mathrm{a}}+R_{\mathrm{b}}+R_{\mathrm{c}}}$

The canopy resistance $(\mathrm{Rc})$ is calculated as:

$\frac{1}{\mathrm{Rc}}=\frac{1}{r_{\mathrm{s}}+r_{\mathrm{m}}}+\frac{1}{r_{\text {soil }}}+\frac{1}{r_{\mathrm{t}}}$,

where $r_{\mathrm{s}}$ is the stomatal resistance $\left(\mathrm{s} \mathrm{m}^{-1}\right), r_{\mathrm{m}}$ is the mesophyll resistance $\left(\mathrm{s} \mathrm{m}^{-1}\right), r_{\text {soil }}$ is the soil resistance $\left(2941 \mathrm{~s} \mathrm{~m}^{-1}\right)$, and $r_{\mathrm{t}}$ is the cuticular resistance $\left(\mathrm{s} \mathrm{m}^{-1}\right)$.

The quasi-laminar boundary layer $\left(R_{\mathrm{b}}\right)$ is calculated as:

$R_{\mathrm{b}}=2(\mathrm{Sc})^{\frac{2}{3}}(\operatorname{Pr})^{-\frac{2}{3}}(k u *)^{-1}$

where Sc is the Schmidt number (1), Pr is the Prandtl number (0.72), $k$ is the von Karman constant $(0.41)$, and $u *$ is the friction velocity $\left(\mathrm{m} \mathrm{s}^{-1}\right)$. 


\section{Water balance model}

The water balance is based on the DeNitrification and DeComposition (DNDC) model (Li et al. 1992) modified for urban conditions and short-term calculations. The following water fluxes are considered:

$P=T+I+E+R+S$,

where $P$ is precipitation, $T$ is transpiration, $I$ is interception, $E$ is the evaporation, $R$ is runoff, and $S$ is seepage (percolation below the last considered soil layer). The model determines daily potential evapotranspiration from daily temperature based on a modified Thornthwaite equation (Thornthwaite and Mather 1957) and considering the dependency on the latitude (Camargo et al. 1999; Pereira and Pruitt 2004). The potential demand for hourly evaporation was determined by dividing the daily evaporation by 24 , which has shown to work well in various applications where this model has been applied to describe ecosystem processes (Holst et al. 2010; Magh et al. 2019). The interception is assumed to be linearly related to the LAI and retained water evaporates from leaves according to the evaporation demand. Water drawn from the soil by evaporation and transpiration can be calculated as the minimum of either the remaining potential evapotranspiration or water demand, which in turn depends on photosynthesis and the species-specific water-use efficiency (3 $\mathrm{umol} \mathrm{mmol}^{-1}$; Gillner et al. 2015). The soil evaporation was determined from the residual evaporation demand and soil water available below a predefined depth $(0.3 \mathrm{~m})$. The water movement within the soil depends on the difference between the relative water contents of the three adjacent soil layers and is regulated by the soil hydraulic conductivity. For Pariser Platz, we assumed a runoff of $40 \%$ due to the impervious surface and lower soil depth $(0.1,0.2$, and $0.4 \mathrm{~m}$ for the three layers, respectively, compared with $0.2,0.3$, and $0.5 \mathrm{~m}$, respectively, at Bordeaux Platz). A drought index (DI) was defined to limit the stomatal conductance and reduce the Ball-Berry constant $(m)$ from 10 to 3 according to the soil water availability:

$\mathrm{DI}=\frac{(\text { water content }- \text { wilting point })}{(\text { field capacity }- \text { wilting point })}$,

where:

$$
\begin{aligned}
& \text { - if } \mathrm{DI} \leq 0.3 \rightarrow m=3 \\
& \text { - } 0.3<\mathrm{DI}<0.5 \rightarrow m=3+35 \times(\mathrm{DI}-0.3) \\
& \text { - } \mathrm{DI} \geq 0.5 \rightarrow m=10
\end{aligned}
$$

\section{Energy balance model}

Energy reduction based on cooling and shading was evaluated at midday (12:00-15:00, CET). The average hourly transpiration $T\left(\mathrm{ml} \mathrm{h}^{-1} \mathrm{~m}^{-2}\right)$ was converted into energy loss $\left(\mathrm{W} \mathrm{m}^{-2}\right)$ by multiplication with the latent heat of vaporization $L_{\mathrm{V}}$, which is $2450 \mathrm{~J} \mathrm{~kg}^{-1}$ and division by $3600 \mathrm{~s}$ :

$E_{\text {cooling }}=\frac{T \times L_{\mathrm{v}}}{3600}$

The net rate of heat flow to and from a pavement surface $\left(q_{\text {net }}\right)$ can be calculated as follows (Solaimanian and Kennedy 1993):

$\mathrm{q}_{\text {net }}=q_{\mathrm{a}}+q_{\mathrm{s}}-q_{\mathrm{c}}-q_{\mathrm{k}}-q_{\mathrm{r}}$,

where $q_{\mathrm{a}}$ is the absorbed energy from direct solar (shortwave) radiation, $q_{\mathrm{s}}$ is the atmospheric radiation absorbed by the pavement surface, $q_{\mathrm{c}}$ is the convection energy, $q_{\mathrm{k}}$ is the conduction energy, and $q_{\mathrm{r}}$ is the surface emission.

$q_{\mathrm{a}}=(1-a) \times R$,

where $a$ is the albedo $(0.3)$ and $R$ is the direct radiation (determined from the global radiation as described in Spitters et al. 1986).

$q_{\mathrm{s}}=\varepsilon_{\mathrm{a}} \sigma T_{\mathrm{air}}^{4}$

$\varepsilon_{\mathrm{a}}=0.77-0.28 \times 10^{\left(-V_{\mathrm{p}} \times 0.074\right)}\left(\right.$ Geiger 1959), $V_{\mathrm{p}}=$ vapor pressure $(\mathrm{mmHg}), \sigma=$ Stefan-Boltzmann constant $(=5.68 \times$ $\left.10^{-8} \mathrm{~W} \mathrm{~m}^{-2} \mathrm{~K}^{-4}\right), T_{\text {air }}=$ air temperature $(\mathrm{K})$

$q_{\mathrm{c}}=h_{\mathrm{c}}\left(T_{\mathrm{s}}-T_{\mathrm{air}}\right)$

$h_{\mathrm{c}}=$ surface coefficient of heat transfer $=698.24\left[0.00144 T_{\mathrm{m}}{ }^{0.3} U^{0.7}+0.00097\left(T_{\mathrm{s}}-T_{\text {air }}\right)^{0.3}\right], T_{\mathrm{s}}=$ surface temperature $(\mathrm{K}), T_{\mathrm{m}}=$ average of the surface and air temperature $(\mathrm{K}), U=$ average daily wind speed $\left(\mathrm{m} \mathrm{s}^{-1}\right)$

$q_{\mathrm{k}}=-k \frac{T_{d}-T_{\mathrm{s}}}{d}$

$k=$ thermal conductivity $\left(1.65 \mathrm{~W} \mathrm{~m}^{-1} \mathrm{~K}^{-1}\right), d=$ depth (2 m), $T_{d}=$ temperature at depth $d\left(8^{\circ} \mathrm{C}\right)$

$q_{\mathrm{r}}=\varepsilon_{\mathrm{b}} \sigma T_{\mathrm{s}}^{4}$

with

$\varepsilon_{\mathrm{b}}=1.24 \times\left(10 \times V_{\mathrm{p}} / T_{\text {air }}\right)^{\frac{1}{7}}$ (Brutsaert 1982).

The reduction of the direct radiation through the tree crown was calculated using a modified Beer-Lambert law considering a uniform leaf arrangement in the canopy:

$R_{\text {in }}=R \times e^{-k \times \mathrm{LAI}}$,

where $R_{\text {in }}$ is the irradiance under the tree canopy $\left(\mathrm{W} \mathrm{m}^{-2}\right.$ ) and $k$ is the extinction coefficient ( 0.7 for deciduous forest).

The equilibrium temperature at the pavement surface is calculated by setting the net rate of heat flow $\left(q_{\text {net }}\right)$ to 0 :

$q_{\mathrm{a}}+q_{\mathrm{s}}-q_{\mathrm{c}}-q_{\mathrm{k}}-q_{\mathrm{r}}=0$ 
The equation obtained considers surface temperature, air temperature, and temperature at a depth where heat flow can be assumed zero. The surface temperature can be thus calculated by knowing $T_{\text {air }}$ from measurements and assuming a constant annual average temperature $T_{d}\left(8.0^{\circ} \mathrm{C}\right)$ at 2-m depth.

The energy reduction by shading $\left(E_{\text {shading }} ; \mathrm{W} \mathrm{m}^{-2}\right)$ was calculated as the absolute difference between the energy balance outside and inside the tree canopy:

$$
\begin{aligned}
E_{\text {shading }}= & \left|q_{\mathrm{a}, \text { out }}-q_{\mathrm{a}, \text { in }}\right|+\left|q_{\mathrm{s}, \text { out }}-q_{\mathrm{s}, \text { in }}\right|+\left|q_{\mathrm{c}, \text { out }}-q_{\mathrm{c}, \text { in }}\right| \\
& +\left|q_{\mathrm{k}, \text { out }}-q_{\mathrm{k}, \text { in }}\right|+\left|q_{\mathrm{r}, \text { out }}-q_{\mathrm{r}, \text { in }}\right|
\end{aligned}
$$

The total energy reduction $E\left(\mathrm{~W} \mathrm{~m}^{-2}\right)$ was calculated as the sum of $E_{\text {shading }}\left(\mathrm{W} \mathrm{m}^{-2}\right)$ and $E_{\text {cooling }}\left(\mathrm{W} \mathrm{m}^{-2}\right)$.

\section{Results}

The two sites are not significantly different in terms of the air temperature, relative humidity, and vapor pressure deficit. However, wind speed at Bordeaux Platz (mean $=0.9 \mathrm{~m} \mathrm{~s}^{-1}$ ) is much higher than that at Pariser Platz (mean $=0.5 \mathrm{~m} \mathrm{~s}^{-1}$; Fig. 1). Consequently, the resistances of the aerodynamic and quasi-laminar boundary layer were considerably lower at
Bordeaux Platz (on average 105.9 and $60 \mathrm{~s} \mathrm{~m}^{-1}$, respectively) than at Pariser Platz (222.4 and $125.9 \mathrm{~s} \mathrm{~m}^{-1}$, respectively; Fig. 2), which explains the higher transpiration demand at the former location.

During the observation period, the negative soil water potential increased until mid-August when several precipitation events occurred, leading to the replenishment of the soil layers with water and a consequent increase in soil moisture potential. This trend could be represented with the simulation of soil water content, supporting the assumptions made about soil depth and surface sealing. However, recovery of the relative water content at Pariser Platz is lower than that at Bordeaux Platz (Fig. 3) because the water supply is reduced due to larger runoff. Therefore, drought at Pariser Platz is more prolonged, resulting in a persistently low stomatal conductance, while at Bordeaux Platz stomatal, conductance is increasing in the investigated period (Fig. 4).

In order to demonstrate the impact of drought, we simulated the development of the drought index (DI) on stomatal conductance throughout the whole year 2015 for both sites. At the Pariser Platz, the index drops almost to zero while it stays above 0.4 at Bordeaux Platz (Fig. 5). This considerable difference affects the Ball-Berry coefficient $(m)$ and decreases stomatal conductance (gs) at the sealed sites relative to the open place.
Fig. 1 Meteorological conditions at the two study sites. Missing values in Pariser Platz on August 5-6, 2015
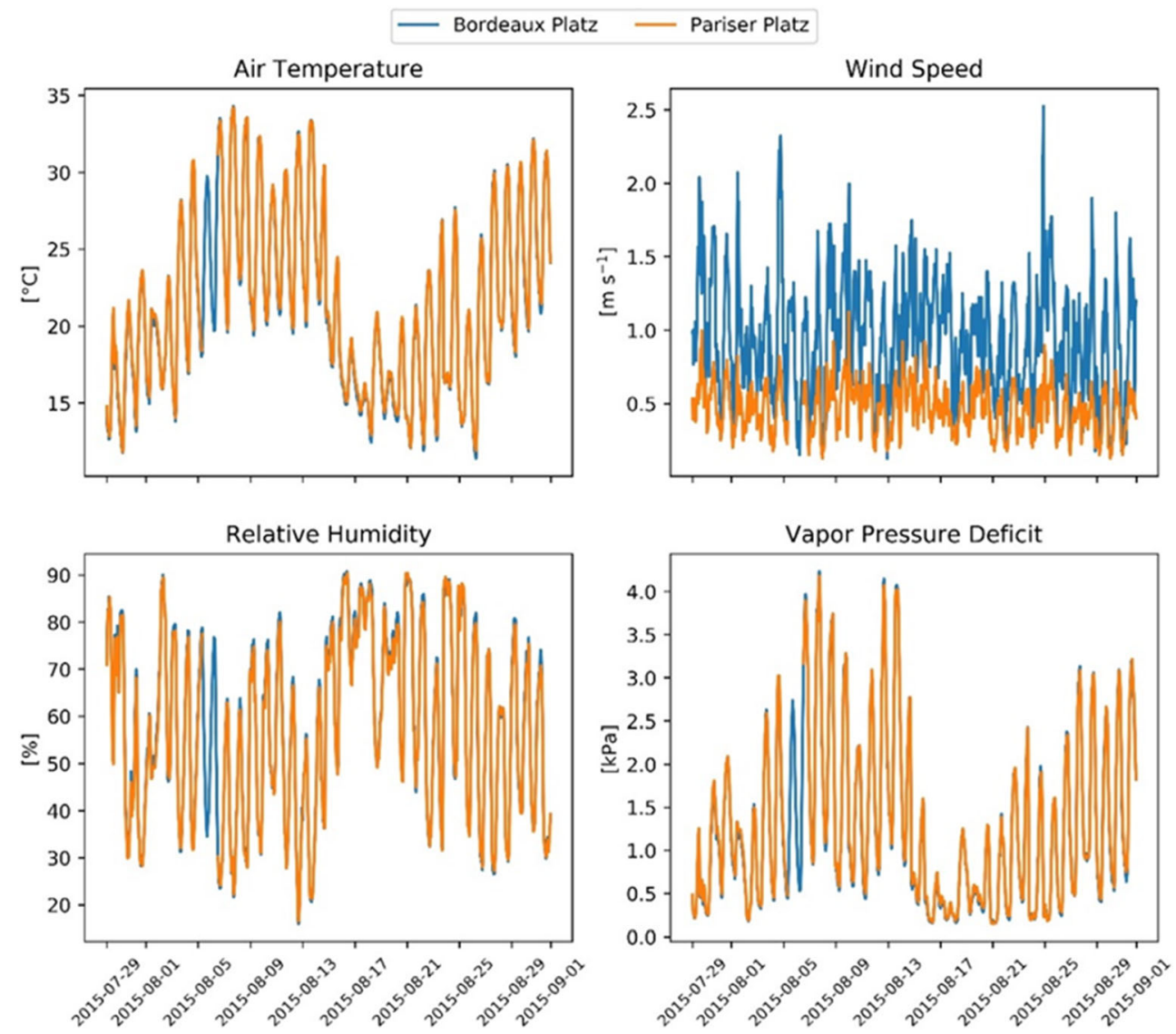
Fig. 2 Model resistances at the two sites. The quasi-laminar boundary layer is referred to as $\mathrm{O}_{3}$

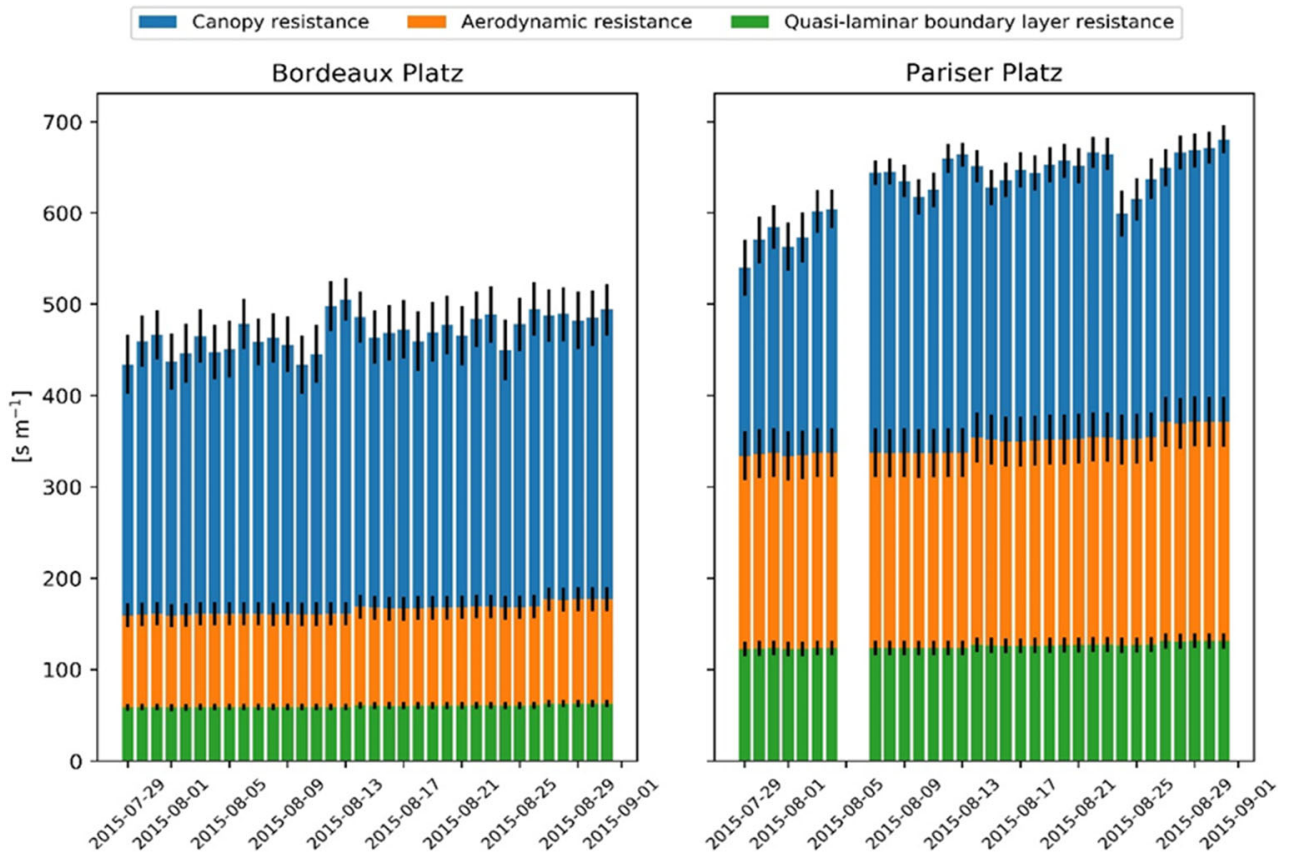

The modeled and measured transpiration values at the two sites overall agree, including the higher water losses at Bordeaux Platz due to higher stomatal conductance, highlighting the ability of the model to cope with the differences between the two sites (Fig. 6).

In a model experiment, we can estimate the temperature effect originating from the shading of the crown to illustrate the usefulness of the model approach. Therefore, we calculate the temperature of an unshaded and a shaded concrete surface based on the recorded weather conditions at the two investigated places. This shows that the simulated surface temperature would be a lot lower under the tree canopy at the hottest days (up to $18.7^{\circ} \mathrm{C}$ in Pariser Platz and $16.2^{\circ} \mathrm{C}$ in Bordeaux Platz; Fig. 7), while during the cool period without much
Fig. 3 Upper panels: Relative water content in each soil layer and measured soil moisture potential. Lower panels: Average daily temperature and rain events in the study period

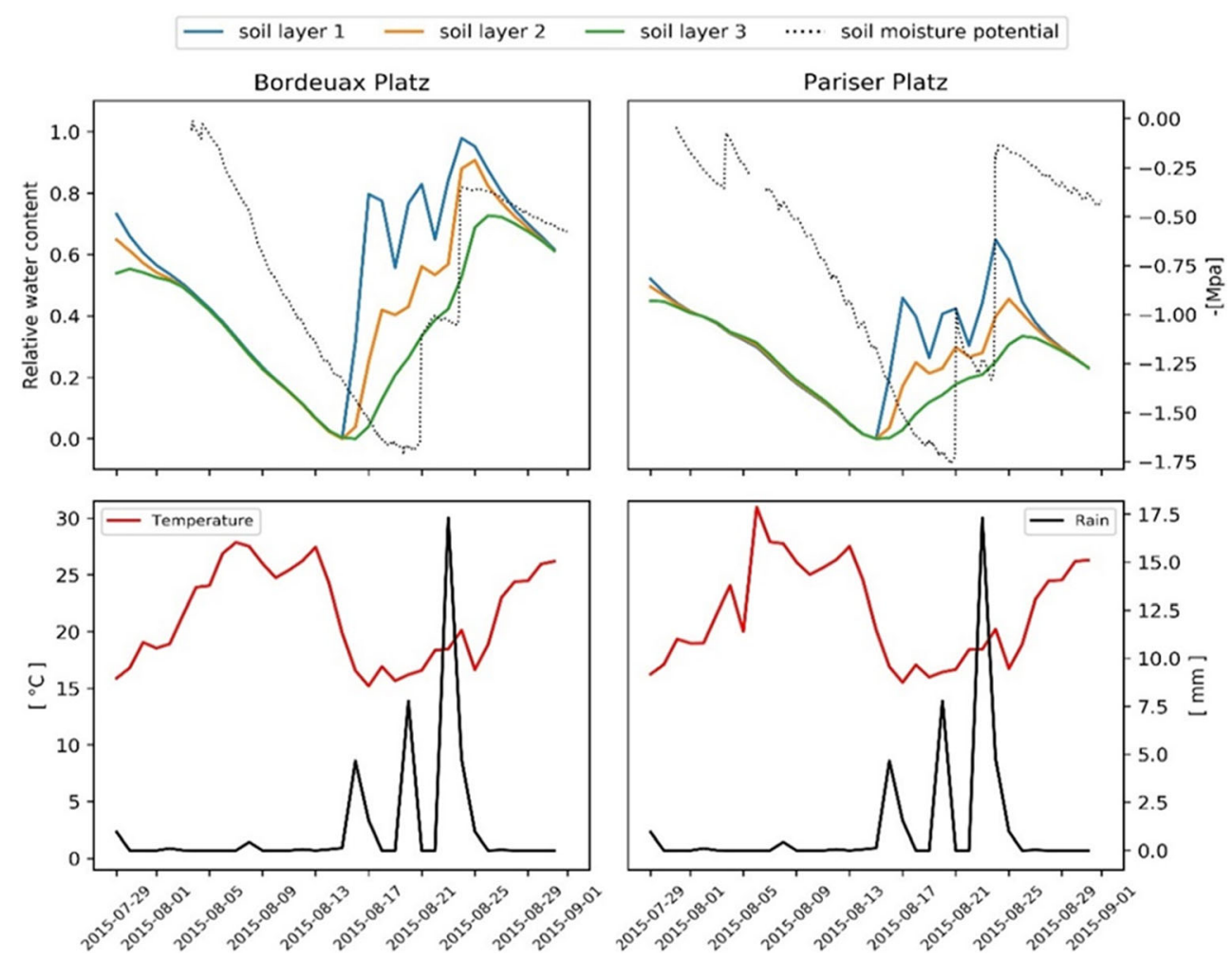




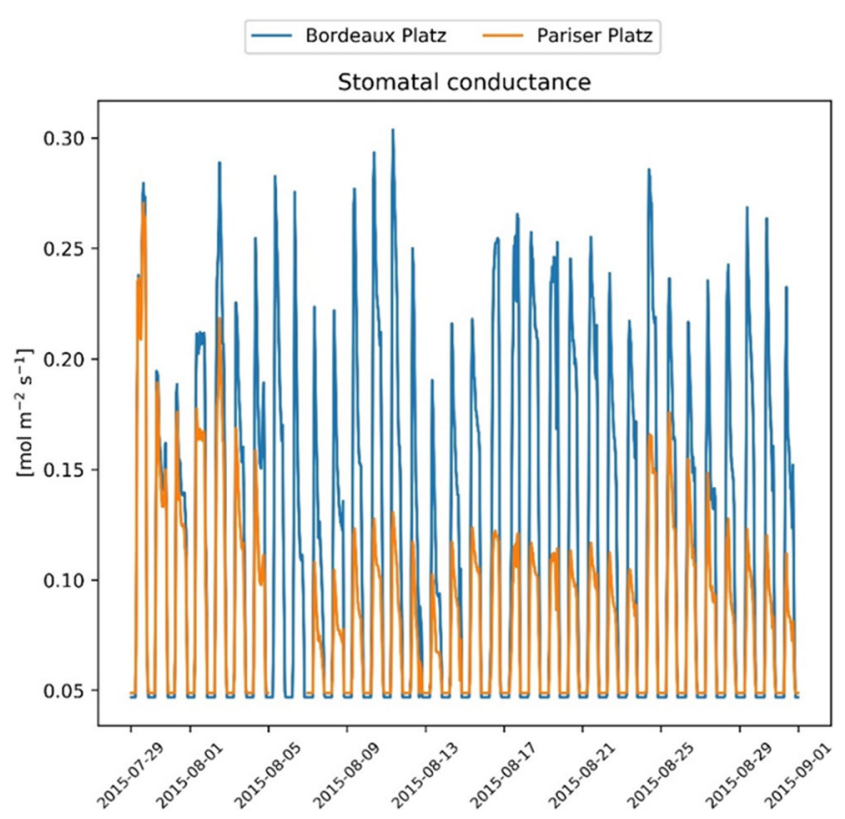

Fig. 4 Stomatal conductance at the two sites

direct radiation, the shading effect is negligible. The differences in temperature regime between the places originate again predominantly from the lower wind speed at Pariser Platz, which limits the heat flow by convection to the surrounding air and thus leads to higher temperatures. On the other side, the surface temperature under shaded conditions at this site is slightly lower because of its slightly higher leaf area index.

The transpiration performance particularly influences the cooling effect at Pariser Platz (mean $=0.03 ; \max =0.04 \mathrm{~kW} /$ $\mathrm{m}^{2}$ ) compared with Bordeaux Platz (mean $=0.05$; $\max =$ $0.08 \mathrm{~kW} / \mathrm{m}^{2}$ ). Instead, the energy reduction by shading is similar at the two locations (mean $=0.3 ; \max =0.5 \mathrm{~kW} / \mathrm{m}^{2}$ ), indicating that the largest energy reduction occurs at midday (Fig. 8). The differences in the stomatal conductance result

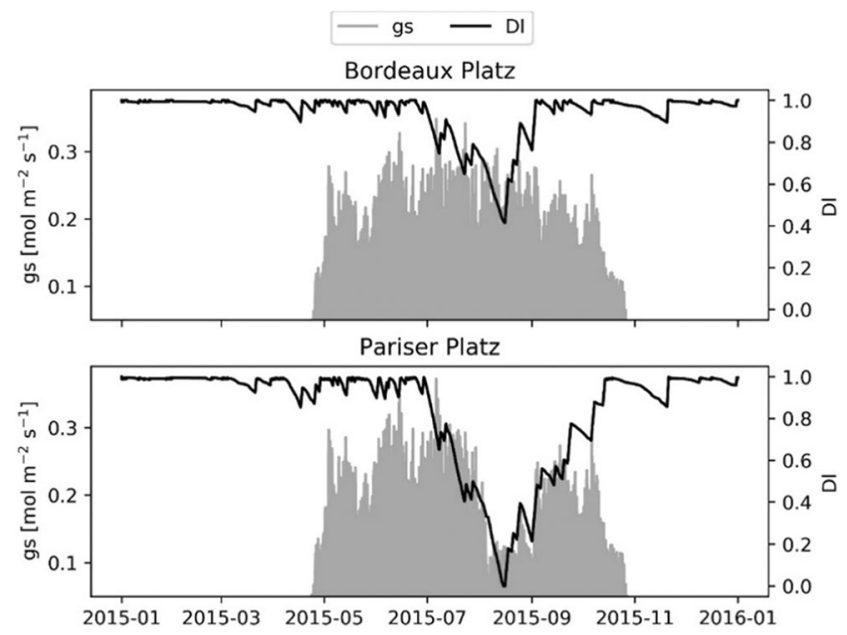

Fig. 5 Drought index (DI) effect on stomatal conductance (gs) at the two sites calculated for the whole year 2015 in remarkable differences in vd, as indicated in Fig. 9. Thus, it can be assumed that the conditions at Bordeaux Platz lead to a higher removal of gaseous pollutants than at Pariser Platz. For sites with comparable ozone formation and transport, this may ultimately lead to a relatively better air quality.

\section{Discussion}

Urban trees can help mitigate urban extreme temperature events, which are expected to be more frequent and more severe in the future (Guerreiro et al. 2018). To better evaluate the efficiency of increased tree abundance, models are required that can be used to determine ecosystem services depending on both tree-specific properties and the (potentially changing) environment. Environmental conditions include direct influences of immediate climate and indirect influences, particularly the soil water availability (Livesley et al. 2016). Increased drought can be expected to affect the plant properties and thus the ecosystem services that are related to water evaporation (cooling) and pollution uptake (Stratópoulos et al. 2019; Zhang et al. 2020). Consequently, water availability impacts must be reflected in a model for decision support. Therefore, we implemented and tested a model that cannot only be used to directly calculate heat mitigation in terms of energy reduction due to cooling and shading but also considers the impact of drought stress on evaporation and the stomatal uptake. A similar approach that link different ecosystem services based on physiological responses has been very recently presented by Delaria and Cohen (2020) although not in the urban context.

The test simulations demonstrate that the energy reduction of urban trees is particularly high at midday on sunny and warm days due to the shading provided by tree crowns. The effectiveness of this process scales with LAI, crown depth, and width (Sanusi et al. 2017). Measurements of the pavement surface temperature for the study site in Munich were carried from Rahman et al. (2017b) reporting an average surface temperature reduction by $15.2{ }^{\circ} \mathrm{C}$ on three warm sunny days (July 21, August 08 and 13, 2015). Our simulations for the same days in August showed a similar average temperature reduction of about $13{ }^{\circ} \mathrm{C}$ for the two sites (Fig. 7). A recent study in which a thermal camera was used to determine the surface temperature change of asphalt, porphyry, and grass based on shading of different tree species, median average cooling values of $16.4,12.9$, and $8.5^{\circ} \mathrm{C}$ was reported, respectively (Speak et al. 2020). In other studies, a maximum hourly cooling of $2.3{ }^{\circ} \mathrm{C}$ based on the shading of a single tree on the building facade (Zhao et al. 2018) and average cooling of the air temperature by trees in streets and courtyards of $2.5{ }^{\circ} \mathrm{C}$ (Shashua-Bar and Hoffman 2004) were determined.

The simulated transpiration effect depends on the meteorological conditions (wind speed, vapor pressure deficit) and 
Fig. 6 Top: Comparison of modeled transpiration and values measured using the sap flow for the sites Bordeaux Platz (left) and Pariser Platz (right). Bottom: Relationship between observed and simulated values

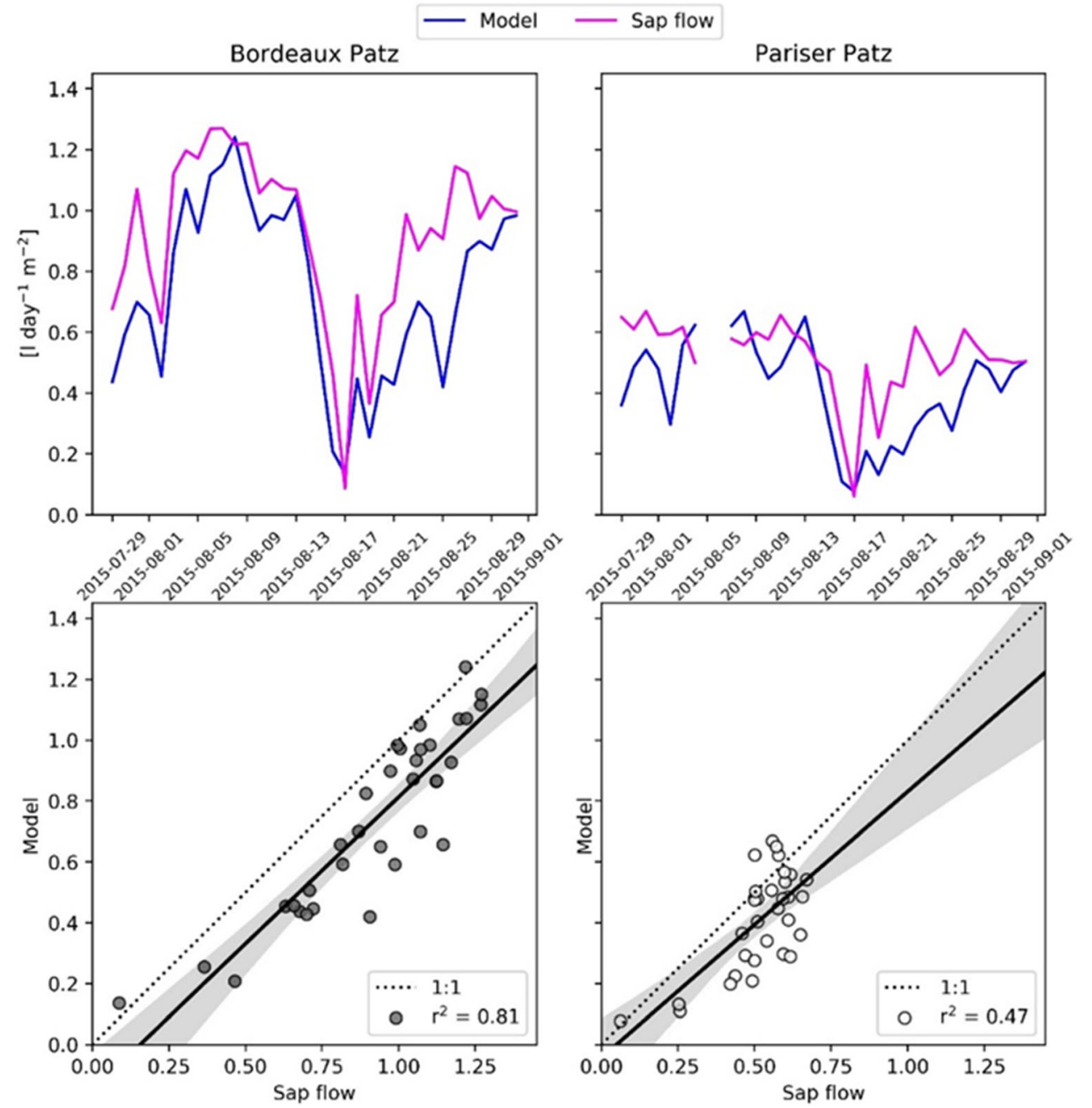

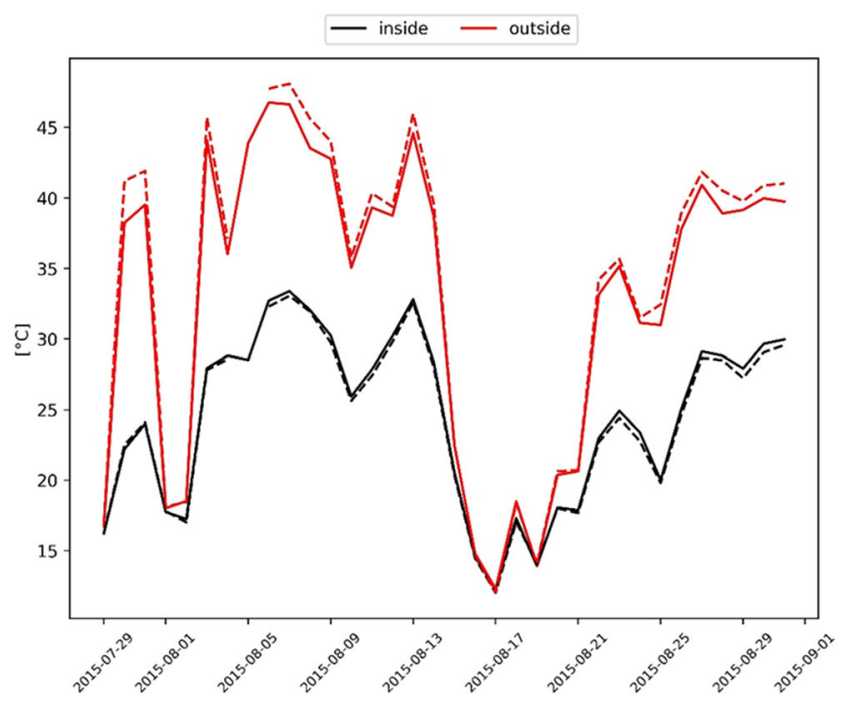

Fig. 7 Simulated surface temperature (of an assumed concrete surface) outside and inside the tree canopy. The solid line is the simulation for Bordeaux Platz and the dashed line for Pariser Platz soil water availability (pervious or impervious surfaces) and represents on average $12 \%$ of the total energy reduction $(15 \%$ at Bordeaux Platz and 9\% at Pariser Platz). Besides a higher aerodynamic and quasi-laminar boundary layer resistance, we attribute the result also to a lower soil water availability in Pariser Platz compared to Bordeaux Platz. It should be acknowledged that the simulated water content is not exactly in temporal agreement with measurements (Fig. 3). However, given the uncertainties in rainfall distribution and amount as well as soil property initialization, the results can still be seen as a confirmation of the model's ability to represent drought. In particular, since it is corroborated by the direct transpiration measurements at both sites (Fig. 6).

The simulated transpiration is in overall well accordance with the measurements although recovery after cool periods is delayed by a few days. This is despite the simulated restriction by soil water limitation is less severe than indicated by measurements of soil water potential during the respective period. A possible explanation is that foliage and thus transpiration demand might increase faster in reality than assumed in the model which would call for a more comprehensive 
Fig. 8 Energy reduction by concrete shading and cooling by transpiration at the two sites at midday

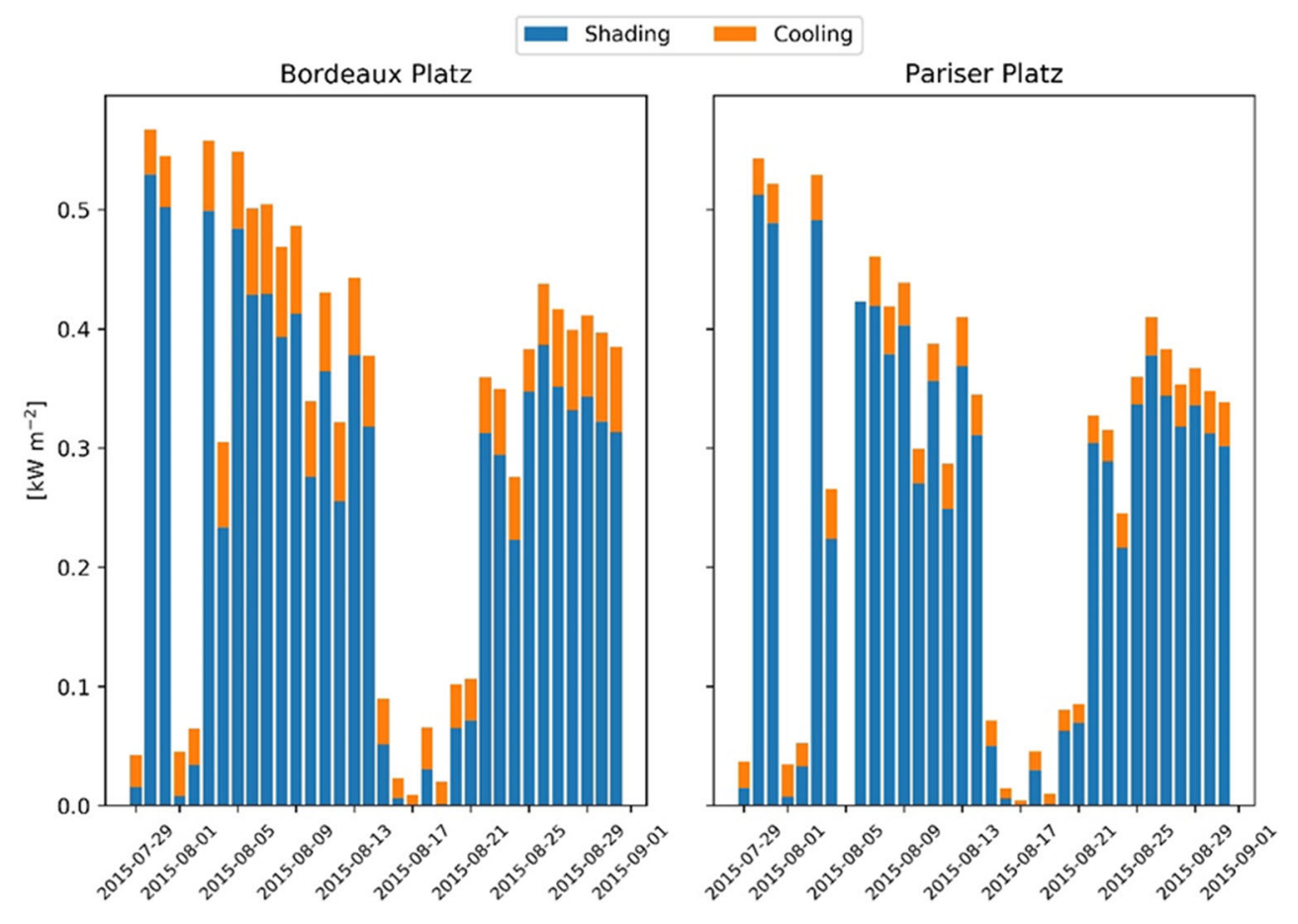

determination of surface temperature. Also, some differences are apparent between the development of soil water potential and the simulated soil water content, indicating either a very inhomogeneous precipitation distribution within the city or a non-linear relation between runoff and percolation that might need to consider ponding or channeling effects from gutters (Meili et al. 2020). The very scattered distribution of sensors, the scarce information about the soil properties, and the assumption of homogeneous soil sealing, however, demand for further evaluation studies in order to determine the importance

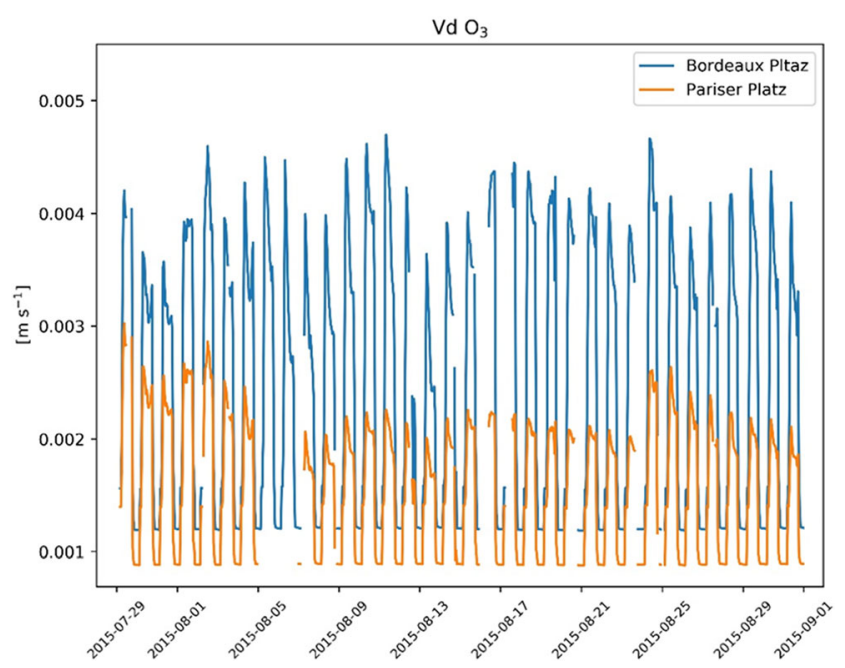

Fig. 9 Simulated dry deposition velocity (vd) of $\mathrm{O}_{3}$ at the two sites. Missing values correspond to hours with precipitation. The differences of $\mathrm{O}_{3}$ uptake at the two sites result from the site-specific stomatal conductance and resistances of different foliage, surface, and soil properties to improve the respective parameterization.

Despite these uncertainties, the differences between the investigated sites have highlighted the importance of considering impervious surfaces, which characterize the urban fabric, enhances the water runoff, and reduces soil water infiltration (Wang et al. 2008). A limited water availability reduces the potential for evaporative cooling, in particular because of transpiration reduction (Gillner et al. 2015). This effect might significantly affect the immediate environment. For example, the results of experimental studies showed that evaporative cooling alone contributes to an air temperature reduction up to $3^{\circ}$ within the canopies (Rahman et al. 2017b, 2020b) and the canopy-to-air temperature difference depends on meteorological conditions, tree species and, urban site-specific characteristics (Meier and Scherer 2012). The cooling effect by transpiration depends to a large extent on stomatal conductance (Tan et al. 2018) and our results are in agreement with measured values at midday on Tilia europaea in Sweden (0.1$0.2 \mathrm{~mol} \mathrm{~m}^{-2} \mathrm{~s}^{-1}$ ) (Konarska et al. 2016). The energy loss due to tree transpiration for commonly planted species in Central Europe including $T$. cordata ranges between 0.059 and $0.075 \mathrm{~kW} \mathrm{~m}^{-2}$ (Rötzer et al. 2019) which is similar to our results in Bordeaux Platz.

We demonstrate that the new model introduced in this study can capture the effect of drought on gaseous pollution uptake, as previously suggested by Wang et al. (2017). This may be of particular importance for future studies in Mediterranean cities characterized by climate with pronounced drought events; neglecting the effects of stomatal 
conductance may result in a significant overestimation of gaseous pollutant deposition (Morani et al. 2014). However, long periods of heat and drought exacerbated by the high percentage of sealed surfaces have also been recorded in cities at higher latitudes, which affected transpiration and reduced cooling (Gillner et al. 2015; Rahman et al. 2017a).

Note that only gaseous air pollution uptake was considered in this study because particle deposition is generally assumed to be independent of stomatal conductance. However, simple estimates based on the velocity of particulate matter that only depend on climate conditions (i.e., wind speed) and leaf area can easily be added (Pace and Grote 2020). Further improvements could then include, for example, that the stomatal conductance interacts with particle deposition, for example, the stomatal functionality decreases due to heavy particle absorption (Burkhardt and Pariyar 2014; Burkhardt et al. 2018). Nevertheless, we think that gaseous uptake by trees - not only of ozone but also of other oxidizing agents such as $\mathrm{SO}_{2}, \mathrm{NO}_{2}$, and $\mathrm{NO}$-will increase in importance since these compounds are not only directly affecting human health but also increase allergenicity of pollen (Di Menno di Bucchianico et al. 2019). Considering species-specific properties is essential to maximize ecosystem services of urban trees because their features or performances are related to the climate and environmental conditions of the locations in which they grow (McCarthy et al. 2011). For example, under drought conditions, only species with anisohydric behavior will be able to provide cooling by transpiration as well as gaseous air pollution removal because other species will close their stomata early (Grote et al. 2016). Thus, it is important to describe both functions in dependence on stomatal conductance and also to determine conductance from water availability. The latter feature provides the means to define irrigation demand under the premise of a minimum conductance desired. Other examples that demonstrate the importance of considering speciesspecific differences when determining ecosystem services is that air pollution or/and high temperatures might particularly occur at times in the year when deciduous trees are leafless. In these circumstances, it is obviously desirable to plant evergreen trees, which have specific water uptake and deposition properties that a model need considering (Massetti et al. 2019). Overall, the arguments indicate that the features of the new model are important to determine ecosystem services of urban trees consistently, and we exemplarily demonstrated that the new model can be used for this purpose, i.e., quantifying temperature mitigation and pollution removal. In further applications, we will demonstrate that the model is also working on a larger range of environmental conditions as well as for different species based on the respective parameterization of crown properties, stomatal behavior, water-use efficiency, and photosynthesis (Kagotani et al. 2016; Stratópoulos et al. 2019).
We would like to highlight that several issues need to be considered in future research for further increases in the precision and usefulness of model-based assessment based on individual tree services. For example, the leaf area and related physiological processes depend on individual competition, which could be introduced to models to obtain a better individual performance estimate (Pace et al. 2018). On the process level, the interaction between ozone and the stomatal conductance might be introduced, that is, the decrease of the stomatal control under high ozone concentrations (Hoshika et al. 2018, 2020). The introduction of such a feature would also provide the means for considering the potential positive effects of reduced ozone concentrations on the water balances. In addition, seasonal responses of trees, such as leaf shedding, xylem embolism, and higher root turnover or the death of trees might be introduced in response to pollution or drought stress (Stratópoulos et al. 2019; Zhang et al. 2019). Finally, not only direct temperature effects but also changes in the air humidity should be simulated based on evaporation, which also improves the human thermal comfort and thus may add to the benefit of urban tree abundance (Upreti et al. 2017; Wang et al. 2018).

\section{Conclusions}

Overall, it has been demonstrated that the newly introduced model can be used to calculate the temperature mitigation and pollutant deposition depending on environmental conditions and species-specific properties. The physiological basis facilitates the simultaneous and consistent consideration of direct shading by canopy coverage, cooling effects by transpiration, and uptake of gaseous pollutants. Based on the introduction of a simple water balance model, which is coupled to the stomatal conductance of trees, the effect of drought can be accounted for. The central role of stomatal conductance for cooling as well as air pollution removal also enables the consideration of pollution feedbacks on the physiology, although this remains to be implemented in the future. Already, the model might be applied for investigations covering longer time periods than one season and larger regions than just one site, but the evaluation for a wider range of environmental conditions (e.g., more prolonged droughts) remains to be demonstrated.

Acknowledgments Open Access funding enabled and organized by Projekt DEAL. The authors would like to thank the Graduiertenzentrum Weihenstephan of Technical University of Munich and Enago (www. enago.com) for the English language review.

Funding This research was supported by the Graduate School for Climate and Environment (GRACE). 
Open Access This article is licensed under a Creative Commons Attribution 4.0 International License, which permits use, sharing, adaptation, distribution and reproduction in any medium or format, as long as you give appropriate credit to the original author(s) and the source, provide a link to the Creative Commons licence, and indicate if changes were made. The images or other third party material in this article are included in the article's Creative Commons licence, unless indicated otherwise in a credit line to the material. If material is not included in the article's Creative Commons licence and your intended use is not permitted by statutory regulation or exceeds the permitted use, you will need to obtain permission directly from the copyright holder. To view a copy of this licence, visit http://creativecommons.org/licenses/by/4.0/.

\section{References}

Baldocchi D (1994) An analytical solution for coupled leaf photosynthesis and stomatal conductance models. Tree Physiol 14:1069-1079. https://doi.org/10.1093/treephys/14.7-8-9.1069

Baldocchi DD, Hicks BB, Camara P (1987) A canopy stomatal resistance model for gaseous deposition to vegetated surfaces. Atmos Environ 21:91-101. https://doi.org/10.1016/0004-6981(87)90274-5

Baldwin JW, Dessy JB, Vecchi GA, Oppenheimer M (2019) Temporally compound heat wave events and global warming: an emerging hazard. Earth's Futur 7:411-427. https://doi.org/10.1029/ 2018EF000989

Bowler DE, Buyung-Ali L, Knight TM, Pullin AS (2010) Urban greening to cool towns and cities: a systematic review of the empirical evidence. Landsc Urban Plan 97:147-155. https://doi.org/10.1016/j. landurbplan.2010.05.006

Brutsaert W (1982) Evaporation into the atmosphere: theory, history, and applications. D.Reidel, Hingham MA

Buccolieri R, Santiago JL, Rivas E, Sanchez B (2018) Review on urban tree modelling in CFD simulations: aerodynamic, deposition and thermal effects. Urban For Urban Green 31:212-220. https://doi. org/10.1016/j.ufug.2018.03.003

Büker P, Morrissey T, Briolat A, Falk R, Simpson D, Tuovinen JP, Alonso R, Barth S, Baumgarten M, Grulke N, Karlsson PE, King J, Lagergren F, Matyssek R, Nunn A, Ogaya R, Peñuelas J, Rhea L, Schaub M, Uddling J, Werner W, Emberson LD (2012) DO 3SE modelling of soil moisture to determine ozone flux to forest trees. Atmos Chem Phys 12:5537-5562. https://doi.org/10.5194/acp-125537-2012

Burkhardt J, Pariyar S (2014) Particulate pollutants are capable to "degrade" epicuticular waxes and to decrease the drought tolerance of Scots pine (Pinus sylvestris L.). Environ Pollut 184:659-667. https://doi.org/10.1016/j.envpol.2013.04.041

Burkhardt J, Zinsmeister D, Grantz DA et al (2018) Camouflaged as degraded wax: hygroscopic aerosols contribute to leaf desiccation, tree mortality, and forest decline. Environ Res Lett 13:085002. https://doi.org/10.1088/1748-9326/aad346

Camargo AP, Marin FR, Sentelhas PC, Picini AG (1999) Adjust of the Thornthwaite's method to estimate the potential evapotranspiration for arid and superhumid climates, based on daily temperature amplitude. Bras Agrometeorol 7:251-257

Delaria ER, Cohen RC (2020) A model-based analysis of foliar NOx deposition. Atmos Chem Phys 20:2123-2141. https://doi.org/10. 5194/acp-20-2123-2020

Di Menno di Bucchianico A, Brighetti MA, Cattani G et al (2019) Combined effects of air pollution and allergens in the city of Rome. Urban For Urban Green 37:13-23. https://doi.org/10.1016/ j.ufug.2018.04.001
Emberson LD, Ashmore MR, Cambridge HM et al (2000) Modelling stomatal ozone flux across Europe. Environ Pollut 109:403-413. https://doi.org/10.1016/S0269-7491(00)00043-9

Endreny T, Santagata R, Perna A, Stefano CD, Rallo RF, Ulgiati S (2017) Implementing and managing urban forests: a much needed conservation strategy to increase ecosystem services and urban wellbeing. Ecol Model 360:328-335. https://doi.org/10.1016/j.ecolmodel. 2017.07.016

Farquhar GD, Von Caemmerer S, Berry J a. (1980) A biochemical model of photosynthesis CO2 fixation in leaves of C3 species. Planta 149: 78-90

Fitzky AC, Sandén H, Karl T, Fares S, Calfapietra C, Grote R, Saunier A, Rewald B (2019) The interplay between ozone and urban vegetation - BVOC emissions, ozone deposition, and tree ecophysiology. Front For Glob Chang 2:1-17. https://doi.org/10.3389/ffgc. 2019.00050

Geiger R (1959) The climate near the ground. Harvard University Press, Cambridge

Gillner S, Korn S, Roloff A (2015) Leaf-gas exchange of five tree species at urban street sites. Arboric Urban For 41:113-124

Gillner S, Vogt J, Tharang A, Dettmann S, Roloff A (2015) Role of street trees in mitigating effects of heat and drought at highly sealed urban sites. Landsc Urban Plan 143:33-42. https://doi.org/10.1016/j. landurbplan.2015.06.005

Grote R, Samson R, Alonso R, Amorim JH, Cariñanos P, Churkina G, Fares S, Thiec DL, Niinemets Ü, Mikkelsen TN, Paoletti E, Tiwary A, Calfapietra C (2016) Functional traits of urban trees: air pollution mitigation potential. Front Ecol Environ 14:543-550. https://doi. org/10.1002/fee. 1426

Guerreiro SB, Dawson RJ, Kilsby C, Lewis E, Ford A (2018) Future heatwaves, droughts and floods in 571 European cities. Environ Res Lett 13:3. https://doi.org/10.1088/1748-9326/aaaad3

Guo Y, Gasparrini A, Li S, Sera F, Vicedo-Cabrera AM, de Sousa Zanotti Stagliorio Coelho M, Saldiva PHN, Lavigne E, Tawatsupa B, Punnasiri K, Overcenco A, Correa PM, Ortega NV, Kan H, Osorio S, Jaakkola JJK, Ryti NRI, Goodman PG, Zeka A, Michelozzi P, Scortichini M, Hashizume M, Honda Y, Seposo X, Kim H, Tobias A, Íñiguez C, Forsberg B, Åström DO, Guo YL, Chen BY, Zanobetti A, Schwartz J, Dang TN, van DD, Bell ML, Armstrong B, Ebi KL, Tong S (2018) Quantifying excess deaths related to heatwaves under climate change scenarios: a multicountry time series modelling study. PLoS Med 15:1-17. https://doi.org/10. 1371/journal.pmed.1002629

Harley PC, Thomas RB, Reynolds JF, Strain BR (1992) Modelling photosynthesis of cotton grown in elevated CO2. Plant Cell Environ 15: 271-282. https://doi.org/10.1111/j.1365-3040.1992.tb00974.x

Hirabayashi S, Kroll CN, Nowak DJ (2015) i-Tree eco dry deposition model descriptions

Holst J, Grote R, Offermann C, Ferrio JP, Gessler A, Mayer H, Rennenberg H (2010) Water fluxes within beech stands in complex terrain. Int J Biometeorol 54:23-36. https://doi.org/10.1007/s00484009-0248-X

Hoshika Y, Fares S, Pellegrini E, Conte A, Paoletti E (2020) Water use strategy affects avoidance of ozone stress by stomatal closure in Mediterranean trees - a modelling analysis. Plant Cell Environ 43: 611-623. https://doi.org/10.1111/pce.13700

Hoshika Y, Watanabe M, Carrari E, Paoletti E, Koike T (2018) Ozoneinduced stomatal sluggishness changes stomatal parameters of Jarvis-type model in white birch and deciduous oak. Plant Biol 20: 20-28. https://doi.org/10.1111/plb.12632

Hosker RP, Lindberg SE (1982) Review: Atmospheric deposition and plant assimilation of gases and particles. Atmos Environ 16:889 910. https://doi.org/10.1016/0004-6981(82)90175-5

Kagotani Y, Nishida K, Kiyomizu T, Sasaki K, Kume A, Hanba YT (2016) Photosynthetic responses to soil water stress in summer in two Japanese urban landscape tree species (Ginkgo biloba and 
Prunus yedoensis): effects of pruning mulch and irrigation management. Trees - Struct Funct 30:697-708. https://doi.org/10.1007/ s00468-015-1312-2

Konarska J, Uddling J, Holmer B, Lutz M, Lindberg F, Pleijel H, Thorsson S (2016) Transpiration of urban trees and its cooling effect in a high latitude city. Int J Biometeorol 60:159-172. https://doi.org/ 10.1007/s00484-015-1014-x

Kramer JP (1983) Water relations of plants. Academic Press, Cambridge

Krayenhoff ES, Christen A, Martilli A, Oke TR (2014) A multi-layer radiation model for urban neighbourhoods with trees. BoundaryLayer Meteorol 151:139-178. https://doi.org/10.1007/s10546-0139883-1

Lee SH, Park SU (2008) A vegetated urban canopy model for meteorological and environmental modelling. Boundary-Layer Meteorol 126:73-102. https://doi.org/10.1007/s10546-007-9221-6

Li C, Frolking S, Frolking TA (1992) A model of nitrous oxide evolution from soil driven by rainfall events: 2. Model applicat J Geophys Res 97:9777-9783. https://doi.org/10.1029/92jd00510

Li Q, Wang ZH (2018) Large-eddy simulation of the impact of urban trees on momentum and heat fluxes. Agric For Meteorol 255:44-56. https://doi.org/10.1016/j.agrformet.2017.07.011

Lin J, Kroll CN, Nowak DJ, Greenfield EJ (2019) A review of urban forest modeling: implications for management and future research. Urban For Urban Green 43:126366. https://doi.org/10.1016/j.ufug. 2019.126366

Livesley SJ, McPherson EG, Calfapietra C (2016) The urban forest and ecosystem services: impacts on urban water, heat, and pollution cycles at the tree, street, and city scale. J Environ Qual 45:119 124. https://doi.org/10.2134/jeq2015.11.0567

Magh RK, Bonn B, Grote R et al (2019) Drought superimposes the positive effect of silver fir on water relations of european beech in mature forest stands. Forests 10:897. https://doi.org/10.3390/ f10100897

Massetti L, Petralli M, Napoli M, Brandani G, Orlandini S, Pearlmutter D (2019) Effects of deciduous shade trees on surface temperature and pedestrian thermal stress during summer and autumn. Int $\mathrm{J}$ Biometeorol 63:467-479. https://doi.org/10.1007/s00484-01901678-1

McCarthy HR, Pataki DE, Darrel Jenerette G (2011) Plant water-use efficiency as a metric of urban ecosystem services. Ecol Appl 21: 3115-3127. https://doi.org/10.1890/11-0048.1

Mcpherson EG, Simpson JR (1999) Carbon dioxide reduction through urban forestry: guidelines for professional and volunteer tree planters. Albany, CA

Meier F, Scherer D (2012) Spatial and temporal variability of urban tree canopy temperature during summer 2010 in Berlin, Germany. Theor Appl Climatol 110:373-384. https://doi.org/10.1007/s00704-0120631-0

Meili N, Manoli G, Burlando P, Bou-Zeid E, Chow WTL, Coutts AM, Daly E, Nice KA, Roth M, Tapper NJ, Velasco E, Vivoni ER, Fatichi S (2020) An urban ecohydrological model to quantify the effect of vegetation on urban climate and hydrology (UT\&C v1.0). Geosci Model Dev 13:335-362. https://doi.org/10.5194/gmd-13335-2020

Monteith JL, Unsworth MH (2013) Principles of envirionmental physics, 4th Edi. edn. Academic Press, New York

Morani A, Nowak D, Hirabayashi S, Guidolotti G, Medori M, Muzzini V, Fares S, Mugnozza GS, Calfapietra C (2014) Comparing i-Tree modeled ozone deposition with field measurements in a periurban Mediterranean forest. Environ Pollut 195:202-209. https://doi.org/ 10.1016/j.envpol.2014.08.031

Norton BA, Coutts AM, Livesley SJ, Harris RJ, Hunter AM, Williams NSG (2015) Planning for cooler cities: a framework to prioritise green infrastructure to mitigate high temperatures in urban landscapes. Landsc Urban Plan 134:127-138. https://doi.org/10.1016/j. landurbplan.2014.10.018
Nowak DJ, Crane DE, Stevens JC et al (2008) A ground-based method of assessing urban forest structure and ecosystem services. Arboric Urban For 34:347-358

Oke TR (2002) Boundary layer climates

Pace R, Biber P, Pretzsch H, Grote R (2018) Modeling ecosystem services for park trees: sensitivity of i-tree eco simulations to light exposure and tree species classification. Forests 9:1-18. https://doi. org/10.3390/ 9020089

Pace R, Grote R (2020) Deposition and resuspension mechanisms into and from tree canopies: a study modeling particle removal of conifers and broadleaves in different cities. Front For Glob Chang 3:26. https://doi.org/10.3389/ffgc.2020.00026

Pereira AR, Pruitt WO (2004) Adaptation of the Thornthwaite scheme for estimating daily reference evapotranspiration. Agric Water Manag 66:251-257. https://doi.org/10.1016/j.agwat.2003.11.003

Perkins SE, Alexander LV, Nairn JR (2012) Increasing frequency, intensity and duration of observed global heatwaves and warm spells. Geophys Res Lett 39:1-5. https://doi.org/10.1029/2012GL053361

Rahman MA, Moser A, Gold A, Rötzer T, Pauleit S (2018) Vertical air temperature gradients under the shade of two contrasting urban tree species during different types of summer days. Sci Total Environ 633:100-111. https://doi.org/10.1016/j.scitotenv.2018.03.168

Rahman MA, Moser A, Rötzer T, Pauleit S (2017a) Microclimatic differences and their influence on transpirational cooling of Tilia cordata in two contrasting street canyons in Munich, Germany. Agric For Meteorol 232:443-456. https://doi.org/10.1016/j. agrformet.2016.10.006

Rahman MA, Moser A, Rötzer T, Pauleit S (2017b) Within canopy temperature differences and cooling ability of Tilia cordata trees grown in urban conditions. Build Environ 114:118-128. https://doi.org/10. 1016/j.buildenv.2016.12.013

Rahman MA, Stratopoulos LMF, Moser-Reischl A, Zölch T, Häberle KH, Rötzer T, Pretzsch H, Pauleit S (2020a) Traits of trees for cooling urban heat islands: a meta-analysis. Build Environ 170: 106606. https://doi.org/10.1016/j.buildenv.2019.106606

Rahman MA, Hartmann C, Moser-Reischl A, von Strachwitz MF, Paeth H, Pretzsch H, Pauleit S, Rötzer T (2020b) Tree cooling effects and human thermal comfort under contrasting species and sites. Agric For Meteorol 287:107947. https://doi.org/10.1016/j.agrformet. 2020.107947

Robine JM, Cheung SLK, Le Roy S et al (2008) Death toll exceeded 70, 000 in Europe during the summer of 2003. Comptes Rendus - Biol 331:171-178. https://doi.org/10.1016/j.crvi.2007.12.001

Rötzer T, Rahman MA, Moser-Reischl A, Pauleit S, Pretzsch H (2019) Process based simulation of tree growth and ecosystem services of urban trees under present and future climate conditions. Sci Total Environ 676:651-664. https://doi.org/10.1016/j.scitotenv.2019.04. 235

Sanusi R, Johnstone D, May P, Livesley SJ (2017) Microclimate benefits that different street tree species provide to sidewalk pedestrians relate to differences in plant area index. Landsc Urban Plan 157:502511. https://doi.org/10.1016/j.landurbplan.2016.08.010

Scholz T, Hof A, Schmitt T (2018) Cooling effects and regulating ecosystem services provided by urban trees-Novel analysis approaches using urban tree cadastre data. Sustain 10:712. https://doi.org/10. 3390/su10030712

Shashua-Bar L, Hoffman ME (2004) Quantitative evaluation of passive cooling of the UCL microclimate in hot regions in summer, case study: urban streets and courtyards with trees. Build Environ 39: 1087-1099. https://doi.org/10.1016/j.buildenv.2003.11.007

Sicard P, De Marco A, Dalstein-Richier L et al (2016) An epidemiological assessment of stomatal ozone flux-based critical levels for visible ozone injury in Southern European forests. Sci Total Environ 541:729-741. https://doi.org/10.1016/j.scitotenv.2015.09.113 
Solaimanian M, Kennedy TW (1993) Predicting maximum pavement surface temperature using maximum air temperature and hourly solar radiation. Transp Res Rec:1-11

Speak A, Montagnani L, Wellstein C, Zerbe S (2020) The influence of tree traits on urban ground surface shade cooling. Landsc Urban Plan 197:103748. https://doi.org/10.1016/j.landurbplan.2020. 103748

Spitters CJT, Toussaint HAJM, Goudriaan J (1986) Separating the diffuse and direct component of global radiation and its implications for modeling canopy photosynthesis Part I. Components of incoming radiation. Agric For Meteorol 38:217-229. https://doi.org/10.1016/ 0168-1923(86)90060-2

Stratópoulos LMF, Zhang C, Duthweiler S, Häberle KH, Rötzer T, Xu C, Pauleit S (2019) Tree species from two contrasting habitats for use in harsh urban environments respond differently to extreme drought. Int J Biometeorol 63:197-208. https://doi.org/10.1007/s00484-0181653-9

Stratópoulos LMF, Zhang C, Häberle KH et al (2019) Effects of drought on the phenology, growth, and morphological development of three urban tree species and cultivars. Sustain 11:1-15. https://doi.org/10. 3390/su11185117

Tan PY, Wong NH, Tan CL, Jusuf SK, Chang MF, Chiam ZQ (2018) A method to partition the relative effects of evaporative cooling and shading on air temperature within vegetation canopy. J Urban Ecol 4:1-11. https://doi.org/10.1093/jue/juy012

Thornthwaite CW, Mather JR (1957) Instructions and tables for computing potential evapotranspiration and the water balance. Publ Climatol 10:183-311

Tiwari S, Grote R, Churkina G, Butler T (2016) Ozone damage, detoxification and the role of isoprenoids-new impetus for integrated models. Funct Plant Biol 43:324-336. https://doi.org/10.1071/ FP15302

Upreti R, Wang ZH, Yang J (2017) Radiative shading effect of urban trees on cooling the regional built environment. Urban For Urban Green 26:18-24. https://doi.org/10.1016/j.ufug.2017.05.008

Wang J, Endreny TA, Nowak DJ (2008) Mechanistic simulation of tree effects in an urban water balance model. J Am Water Resour Assoc 44:75-85. https://doi.org/10.1111/j.1752-1688.2007.00139.x

Wang W, Wang H, Xiao L, He X, Zhou W, Wang Q, Wei C (2018) Microclimate regulating functions of urban forests in Changchun city (North-east China) and their associations with different factors. IForest 11:140-147. https://doi.org/10.3832/ifor2466-010

Wang Y, Xie Y, Dong W, Ming Y, Wang J, Shen L (2017) Adverse effects of increasing drought on air quality via natural processes. Atmos Chem Phys 17:12827-12843. https://doi.org/10.5194/acp$17-12827-2017$
Watts N, Amann M, Arnell N, Ayeb-Karlsson S, Belesova K, Boykoff M, Byass P, Cai W, Campbell-Lendrum D, Capstick S, Chambers J, Dalin C, Daly M, Dasandi N, Davies M, Drummond P, Dubrow R, Ebi KL, Eckelman M, Ekins P, Escobar LE, Fernandez Montoya L, Georgeson L, Graham H, Haggar P, Hamilton I, Hartinger S, Hess J, Kelman I, Kiesewetter G, Kjellstrom T, Kniveton D, Lemke B, Liu Y, Lott M, Lowe R, Sewe MO, Martinez-Urtaza J, Maslin M, McAllister L, McGushin A, Jankin Mikhaylov S, Milner J, Moradi-Lakeh M, Morrissey K, Murray K, Munzert S, Nilsson M, Neville T, Oreszczyn T, Owfi F, Pearman O, Pencheon D, Phung D, Pye S, Quinn R, Rabbaniha M, Robinson E, Rocklöv J, Semenza JC, Sherman J, Shumake-Guillemot J, Tabatabaei M, Taylor J, Trinanes J, Wilkinson P, Costello A, Gong P, Montgomery H (2019) The 2019 report of the lancet countdown on health and climate change: ensuring that the health of a child born today is not defined by a changing climate. Lancet 394:1836-1878. https://doi. org/10.1016/S0140-6736(19)32596-6

Wilby RL (2003) Past and projected trends in London's Urban heat island. Weather 58:251-260. https://doi.org/10.1256/wea.183.02

Yang Y, Endreny TA, Nowak DJ (2013) A physically based analytical spatial air temperature and humidity model. J Geophys Res Atmos 118:10449-10463. https://doi.org/10.1002/jgrd.50803

Zeng F, Gao N (2017) Use of an energy balance model for studying urban surface temperature at microscale. Procedia Eng 205:2956-2966. https://doi.org/10.1016/j.proeng.2017.10.113

Zhang C, Stratopoulos LMF, Pretzsch H, Rötzer T (2019) How do Tilia cordata Greenspire trees cope with drought stress regarding their biomass allocation and ecosystem services? Forests 10:1-14. https://doi.org/10.3390/f10080676

Zhang C, Stratópoulos LMF, Xu C, Pretzsch H, Rötzer T (2020) Article Development of fine root biomass of two contrasting urban tree cultivars in response to drought stress. Forests 11:1-14. https://doi. org/10.3390/f1 1010108

Zhao Q, Yang J, Wang Z-H, Wentz E (2018) Assessing the cooling benefits of tree shade by an outdoor urban physical scale model at Tempe, AZ. Urban Sci 2:4. https://doi.org/10.3390/ urbansci2010004

Zölch T, Maderspacher J, Wamsler C, Pauleit S (2016) Using green infrastructure for urban climate-proofing: an evaluation of heat mitigation measures at the micro-scale. Urban For Urban Green 20: 305-316. https://doi.org/10.1016/j.ufug.2016.09.011

Publisher's Note Springer Nature remains neutral with regard to jurisdictional claims in published maps and institutional affiliations. 